\title{
Seedlessness and Fruit Quality Traits of Gibberellin Induced Parthenocarpic Fruit in Seven Tomato Genotypes (Solanum lycopersicum L.)
}

\author{
Agus Budi Setiawan ${ }^{1}$, Rudi Hari Murti ${ }^{2}$ \& Aziz Purwantoro ${ }^{2}$ \\ ${ }^{1}$ Faculty of Agriculture, Gadjah Mada University, Yogyakarta, Indonesia \\ 2 Genetics and Plant Breeding Laboratory, Faculty of Agriculture, Gadjah Mada University, Yogyakarta, \\ Indonesia \\ Correspondence: Rudi Hari Murti, Genetics and Plant Breeding Laboratory, Faculty of Agriculture, Gadjah Mada \\ University, Jalan Flora Bulaksumur Yogyakarta 55281, Indonesia. Tel: 62-274-563-062. E-mail: \\ rhmurti@ugm.ac.id
}

Received: December 3, 2015 Accepted: January 28, 2016 Online Published: March 15, 2016

doi:10.5539/jas.v8n4p84

URL: http://dx.doi.org/10.5539/jas.v8n4p84

\begin{abstract}
Parthenocarpic fruit development is regulated by a plant hormone, i.e. gibberellin. The response of seven lines of tomato to gibberellin was investigated to distinguish the degree of parthenocarpy and to compare the quality of seedless and seeded fruits. The flower from stage 12 (size $5 \mathrm{~mm}$ ) until 4 days after anthesis was sprayed with $\mathrm{GA}_{3} 0 \mathrm{mmol} / \mathrm{L}$ and $0.06 \mathrm{mmol} / \mathrm{L}$. The treatments were arranged in Randomized Complete Block Design with three replications. $\mathrm{GA}_{3} 0.06 \mathrm{mmol} / \mathrm{L}$ reduced pollen germination, whose pollen germination $(28.98 \%)$ was lower than $0 \mathrm{mmol} / \mathrm{L}(46.06 \%)$. The total numbers of seeds and fertilized seeds of treated fruit were significantly reduced in comparison with the control. Gibberellin application also increased the number of degenerated seeds. Within the genotypes studied, four groups were distinguished, which showed a different degree of parthenocarpy in response to gibberellin application. Kaliurang 206 and A65 are categorized as seedless with a 93.65\% and $89.58 \%$ reduction in the total number of seeds, respectively. Gamato 1 is categorized as low-seeded with an $83.83 \%$ reduction in the total number of seeds. Gamato 3, Gamato 5, and B78 are categorized as medium-seeded with a $69.83-80.85 \%$ reduction in the total number of seeds, whereas A175 is categorized as normal-seeded with a $36.94 \%$ reduction in the total number of seeds. Gibberellin significantly increased the sugar content by $14.04 \%$ and reduced the ascorbic acid content by $9.68 \%$ of parthenocarpic fruits compared with the untreated.
\end{abstract}

Keywords: fruit morphology, genotype response, plant growth regulator, seed formation, seedless fruit

\section{Introduction}

The majority of seeds are undesirable features in many crops, particularly edible fruit. Some seeds have a bitter taste, are hard, and cause a digestive problem. Seeds and their cavities could be replaced by edible fruit tissue and it is more desirable than seeded fruit. Seedless fruits are developed from unfertilized ovary due to the absence of pollination and/or fertilization, and they are therefore called parthenocarpy (Varoquaux, Blanvillain, Delseny, \& Gallois, 2000). Parthenocarpy is a useful trait for industrial purposes, especially the tomato sauce industry because seeds should be removed before processing in order to obtain the best quality of the sauce (Rotino et al., 2005; Sato, Peet, \& Gardner, 2004). In addition, parthenocarpy may improve the quality of the fruit through the increased sugar content of the fruit $\left(1^{\circ}\right.$ Brix higher than normal fruits), high dry matter content, less acidity, less cellulose, and higher contents of carotene and lycopene than seeded fruit (Lukyanenko, 1991).

Several methods have been proven to produce seedless fruits such as triploid tomato (Kaganzur, Mizrahi, Zamir, \& Navot, 1991). Recently, the parthenocarpic transgenic tomato was obtained either by the regulation of auxin synthesis (DefH9-RI-iaaM) (Rotino et al., 2005), rolB (Carmi, Salts, Dedicova, Shabtai, \& Barg, 2003) or regulation of GA signaling repressor i.e. DELLA (Martí et al., 2007). However, those methods require more time and costs than breeding diploid cultivars of tomato. In order to resolve that problem, plant growth regulator can

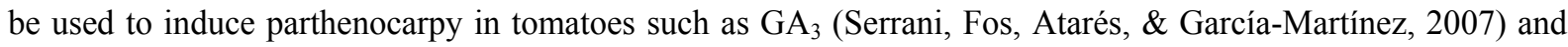
auxin (Serrani, Ruiz-Rivero, Fos, \& García-Martínez, 2008). GA had also been widely used in grape (Jung et al., 2014b) and successfully induced parthenocarpic fruit. 
The Faculty of Agriculture, Gadjah Mada University had developed six new lines of tomatoes, namely Gamato 1, Gamato 3, Gamato 5, A65, A175, and B78. These tomato lines were derived from different parents. Gamato 1, Gamato 3, A65, A175 were derived from GM1 $\times$ Gondol Hijau, whereas Gamato 5 and B78 were derived from GM3 $\times$ Gondol Putih. These tomato lines had obovoid-shape fruit and round-shape fruit, big fruit size, high yield and were suitable for industrial purposes. However, the tomato fruit contained a lot of seeds which could become a problem for the tomato sauce and drink industries. In addition, they will hire more laborers and increase production cost. The objective of this study was to determine the degree of parthenocarpy of new tomato lines exposed to the $\mathrm{GA}_{3}$ application before anthesis and to compare the fruit quality between seedless and seeded tomato fruits.

\section{Method}

\subsection{Plant Material and Experimental Design}

Tomato plants (Solanum lycopersicum L.) cv Gamato 1, Gamato 3, Gamato 5, Kaliurang 206 and tomato lines A65, A175, B78 were used in the experiments. Gamato 1, Gamato 3, A65, A175 are pure lines that derived from GM1 $\times$ Gondol Hijau, while Gamato 5 and B78 are derived from GM3 $\times$ Gondol Putih. Kaliurang 206, a commercial cultivar grown in the wide area, was used as a check cultivar. The experiment had been conducted in the greenhouse of The Seed Development Center of Horticultural Crop, Special Region of Yogyakarta, Indonesia The flowers from stage 12 (size $5 \mathrm{~mm}$ ) until 4 days after anthesis was sprayed with $\mathrm{GA}_{3} 0 \mathrm{mmol} / \mathrm{L}$ and 0.06 $\mathrm{mmol} / \mathrm{L}$. The treatments were arranged in Randomized Complete Block Design with three replications. The experimental unit was consisted of eight plants. The plants were grown in mulched soil (silver and black plastic polyethylene film) at the spacing of $50 \mathrm{~cm} \times 60 \mathrm{~cm}$. Standard agronomic techniques were applied during the growing season from November 2014 to January 2015. Non-emasculated flowers were sprayed with gibberellic acid $\left(\mathrm{GA}_{3}\right)\left(\right.$ Merck) $0.06 \mathrm{mmol} / \mathrm{L}$ and $0 \mathrm{mmol} / \mathrm{L}$ (control). Spraying $\mathrm{GA}_{3}$ started on the first flower (stage 12) according to Brukhin et al. (2003) until 4 days after anthesis with an interval of 3 days for 6 applications from cluster 1 to cluster 3 .

\subsection{Data Collection}

Collected data consisted of pollen germination, the total number of seeds per fruit, the reduction in the number of seeds per fruit (\%), the total number of fertilized seeds per fruit, the reduction in the number of fertilized seeds $(\%)$, the degenerated seeds per fruit, the sugar content, the ascorbic acid content, and fruit firmness. Three plants were chosen as plant sample in all experimental units. Two fruits were sampled from three plant samples in all experimental units for the total number of seeds per fruit, the reduction in the number of seeds per fruit (\%), the total number of fertilized seeds per fruit, the reduction in the number of fertilized seeds (\%), the degenerated seeds per fruit, the sugar content, the ascorbic acid content, and fruit firmness. Two flowers were collected at anthesis (stage 20) for pollen germination assessment from one plant sample in all experimental units. Pollens were germinated on the liquid medium containing $12 \%(\mathrm{w} / \mathrm{v})$ sucrose, $0.01 \%$ boric acid $\left(\mathrm{H}_{3} \mathrm{BO}_{3}\right)$, and $\mathrm{pH} 6.4$ according to Wang et al. (2003). Pollen density was $1500 / 1 \mathrm{ml}$ medium. Pollens were homogenized $1 \mathrm{~min}$ with vortex and incubated at room temperature of $25{ }^{\circ} \mathrm{C}$. The incubated pollen was observed with a microscope (Kruss, Germany) at a magnification of 100x. The picture of each sample was captured 5 replications using Optilab Viewer. The fruit firmness was measured using Penetrometer (Bareiss Pruefgeraetebau GmbH type BS $61 \mathrm{II})$. The sugar content was determined using refractometer (ATAGO Pocket refractometer, Japan, 0-53\% Brix). The ascorbic acid (vitamin C) content was determined by titration method according to Jacobs (1962). The degree of parthenocarpy was determined using a modified method of Mazzucato et al. (1998). Seedless (0-15 seeds), low-seeded (16-25 seeds), medium-seeded (26-50 seeds), and normal-seeded ( $>51$ seeds).

\subsection{Statistical Analysis}

Data were analyzed with Analysis of Variance (ANOVA) according to randomized complete block design and Duncan's Multiple Range Test $(\mathrm{P} \leq 0.05)$. Data processing and statistical analysis were carried out with SAS 9.3. 

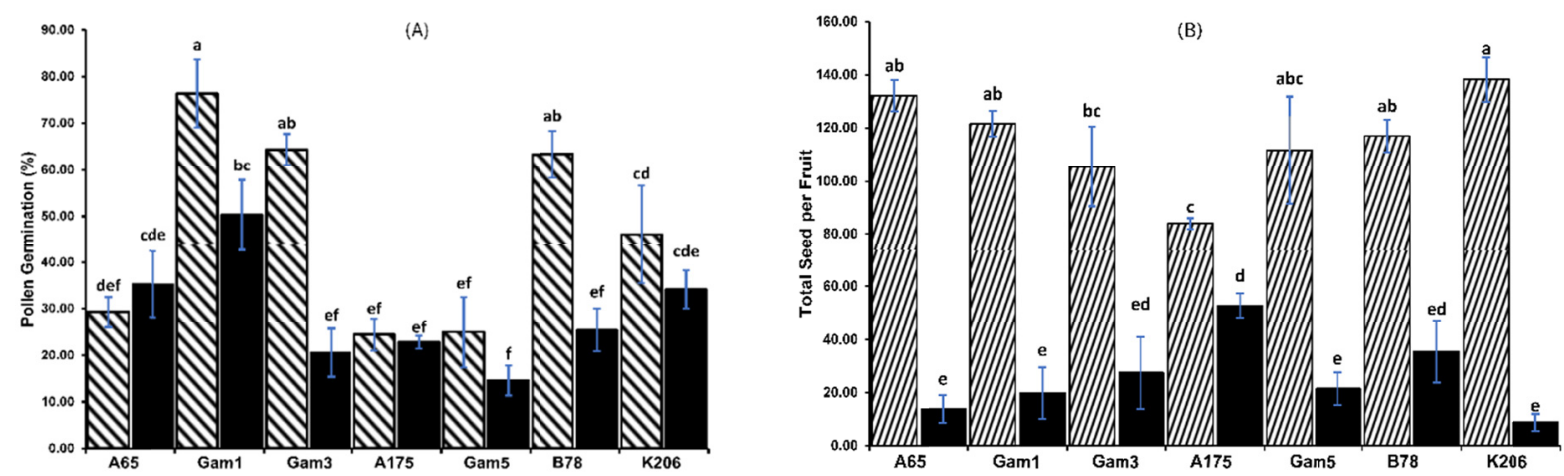

Figure 1. The effect of $\mathrm{GA}_{3}$ on pollen germination (A) and total seed per fruit (B) in seven tomato genotypes

Note. Shading bars correspond to control and black bars correspond to $\mathrm{GA}_{3}$ application $(0.06 \mathrm{mmol} / \mathrm{L})$. Gamato 1 (Gam1), Gamato 3 (Gam3), Gamato 5 (Gam5), Kaliurang 206 (K206). Bars followed by the same letter are not significantly different at $\mathrm{P} \leq 0.05$. Blue bars are the standard deviation.

\section{Results and Discussion}

\subsection{Pollen Germination}

Plants are categorized as seedless fruit if they produced the fruit without seed, followed by seed abortion or have a much-reduced number of seeds (Varoquaux et al., 2000). It can be induced by using plant hormones, particularly gibberellin. The Figure 1A showed that gibberellin applied before anthesis to a non-emasculated flower of tomato reduced pollen germination, inhibited normal seed development and triggered parthenocarpic fruit development as shown in the Figure 1B. This result was in accordance with a previous study which had been reported that gibberellin inhibited the pollen tube growth at high concentration (Singh, Jermakow, \& Swain, 2002).

The concentration of $\mathrm{GA}_{3} 0.06 \mathrm{mmol} / \mathrm{L}$ significantly reduced pollen germination on Gamato 1 , Gamato 3, and B78 whose pollen germination were lower (20.49-50.28\%) than that of the control. Sugiura and Inaba (1966) reported that Delaware grapes treated with gibberellin at pre-bloom reduced pollen germination due to the reduction of respiration rate and enzyme activities of pollen, while A65, A175, Gamato 5, and Kaliurang 206 did not show significant differences on pollen germination between $\mathrm{GA}_{3} 0.06 \mathrm{mmol} / \mathrm{L}$ and $0 \mathrm{mmol} / \mathrm{L}$. However, A65 treated with $\mathrm{GA}_{3} 0.06 \mathrm{mmol} / \mathrm{L}$ had higher pollen germination $(35.26 \%)$ than that of the control $(29.27 \%)$ although statistically not different. This result suggested that gibberellin acted as pollenicide not only through reducing pollen germination but also probably via development of the coiled pollen tube during penetration in pistil despite it was pollinated with the most viable pollen which has been reported by Okamoto and Miura (2005) and Jung et al. (2014a).

\subsection{Gibberellin-Induced Parthenocarpic Fruit in Tomato Genotypes}

Total seed per fruit is defined as total seed potential, including fertilized and degenerated seed. Figure 1B showed that total seed per fruit significantly reduced in all genotypes treated with $\mathrm{GA}_{3} 0.06 \mathrm{mmol} / \mathrm{L}$. Kaliurang 206 treated with $\mathrm{GA}_{3} 0.06 \mathrm{mmol} / \mathrm{L}$ had the lowest total seed per fruit but not significantly different compared to other genotypes except A175. Total seed per fruit in control was significantly different compared to the fruit developed from flower treated by $\mathrm{GA}_{3} 0.06 \mathrm{mmol} / \mathrm{L}$. This result suggested that applying gibberellin before anthesis to non-emasculated flowers of tomato reduced the total seeds per fruit and triggered parthenocarpic fruit development. A similar result was reported on grape treated by gibberellin before full-bloom (Jung et al., 2014b). 

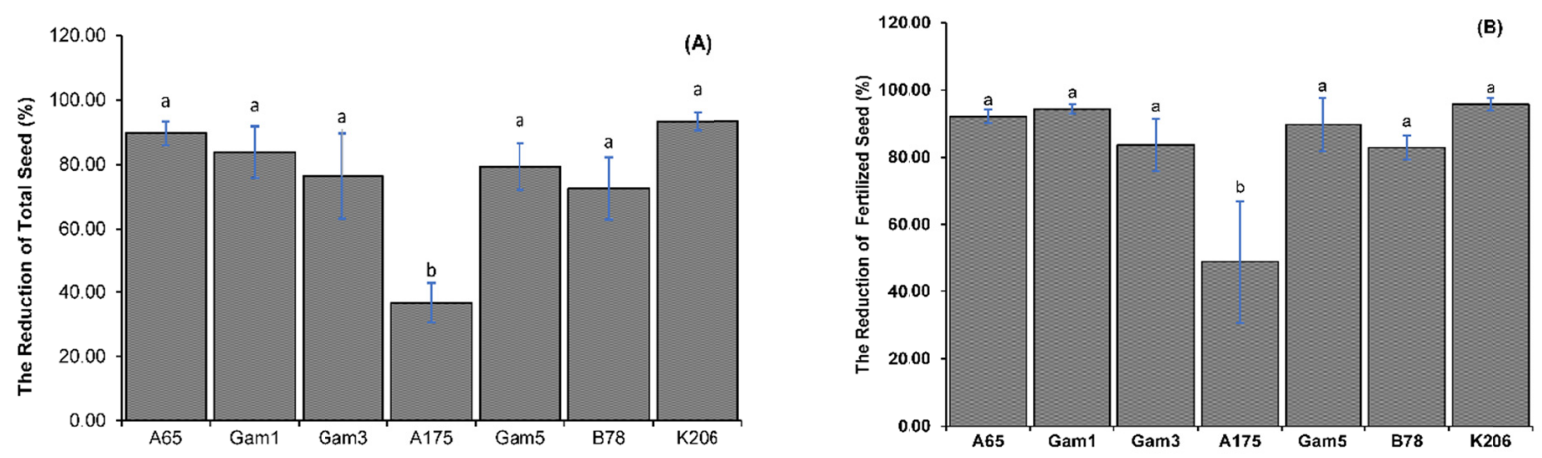

Figure 2. The effect of $\mathrm{GA}_{3}$ application on the reduction in the number of seeds (A) and in the number of fertilized seeds (B)

Note. Gamato 1 (Gam1), Gamato 3 (Gam3), Gamato 5 (Gam5), Kaliurang 206 (K206). Bars followed by the same letter are not significantly different at $\mathrm{P} \leq 0.05$. Blue bars are the standard deviation.

The Figure 2A showed that Kaliurang 206 had the highest reduction in the number of seeds (93.65\%) and did not show significant difference compared to other genotypes except A175 which had the lowest reduction in the number of seeds (36.94\%), while A65, Gamato 1, Gamato 3, Gamato 5, and B78 had a reduction in the number of seeds between $69.83 \%-89.58 \%$. Table 1 showed that according to the modified method of Mazzucato et al. (1998), four groups were distinguished based on seed reduction, which showed a different degree of parthenocarpy in response to gibberellin application. Kaliurang 206 and A65 are categorized as seedless. Gamato 1 is categorized as low-seeded. Gamato 3, Gamato 5, and B78 are categorized as medium-seeded, while A175 is categorized as normal-seeded. A65, Gamato 1, Gamato 3, and A175 had the same parent (GM1 $\times$ Gondol Hijau). Although genotypes derived from the same ancestry, their responses to form parthenocarpic fruit were quite different. This result suggested there was variability within genotypes which showed a different degree of parthenocarpy. The result was similar to Tiwari, Dassen, and Heuvelink (2007) that eleven genotypes of sweet pepper derived from different parents showed different expression of parthenocarpy in response to normal and low night temperature.

Table 1. The degree of parthenocarpy and the comparison of degenerated seed per fruit, sugar content (\% Brix), ascorbic acid content (mg/100 g Fresh Weight), and fruit firmness in seven tomato genotypes

\begin{tabular}{llllll}
\hline Genotypes & $\begin{array}{l}\text { Degree of } \\
\text { Parthenocarpy }\end{array}$ & $\begin{array}{l}\text { The number of } \\
\text { degenerated seeds per fruit }\end{array}$ & Sugar Content & $\begin{array}{l}\text { Ascorbic acid } \\
\text { content }\end{array}$ & Fruit Firmness \\
\hline A65 & Seedless & $3.11 \pm 2.99^{\mathrm{a}}$ & $6.61 \pm 1.28^{\mathrm{a}}$ & $43.61 \pm 9.86^{\mathrm{b}}$ & $39.65 \pm 2.72^{\mathrm{b}}$ \\
Gamato 1 & Low & $15.78 \pm 13.58^{\mathrm{a}}$ & $4.75 \pm 0.85^{\mathrm{b}}$ & $41.95 \pm 4.40^{\mathrm{b}}$ & $45.17 \pm 5.47^{\mathrm{ab}}$ \\
Gamato 3 & Medium & $10.06 \pm 7.79^{\mathrm{a}}$ & $6.05 \pm 0.50^{\mathrm{a}}$ & $33.74 \pm 3.76^{\mathrm{cd}}$ & $42.02 \pm 3.34^{\mathrm{b}}$ \\
A175 & Normal & $10.22 \pm 10.76^{\mathrm{a}}$ & $6.53 \pm 1.07^{\mathrm{a}}$ & $40.63 \pm 4.12^{\mathrm{bc}}$ & $42.63 \pm 2.84^{\mathrm{ab}}$ \\
Gamato 5 & Medium & $9.72 \pm 4.55^{\mathrm{a}}$ & $4.97 \pm 0.55^{\mathrm{b}}$ & $31.73 \pm 5.87^{\mathrm{d}}$ & $41.80 \pm 2.05^{\mathrm{b}}$ \\
B78 & Medium & $9.72 \pm 17.39^{\mathrm{a}}$ & $4.93 \pm 0.83^{\mathrm{b}}$ & $52.90 \pm 8.66^{\mathrm{a}}$ & $48.02 \pm 7.80^{\mathrm{a}}$ \\
Kaliurang 206 & Seedless & $2.50 \pm 1.94^{\mathrm{a}}$ & $4.59 \pm 0.33^{\mathrm{b}}$ & $37.59 \pm 5.14^{\mathrm{bcd}}$ & $44.40 \pm 4.13^{\mathrm{ab}}$
\end{tabular}

Note. Means \pm standard deviation in the column marked with the same lowercase letter are not significantly different at $\mathrm{P} \leq 0.05$.

The Figure 3 showed that control produced fruit with a higher number of fertilized seeds than $\mathrm{GA}_{3} 0.06 \mathrm{mmol} / \mathrm{L}$. Kaliurang 206 treated with $\mathrm{GA}_{3} 0 \mathrm{mmol} / \mathrm{L}$ had the highest number of fertilized seeds per fruit, but did not show significant difference compared to other genotypes except A175. Fertilized seed is formed as a consequence of successful double fertilization. The Figure 2B supported that Kaliurang 206 had the highest reduction in the number of fertilized seeds $(96.01 \%)$ and did not show significant difference compared to other genotypes except A175 which had the lowest reduction in the number of fertilized seeds (49.35\%), while A65, Gamato 1, Gamato 
3, Gamato 5, and B78 had a reduction in the number of seeds between $83.33 \%-94.50 \%$.

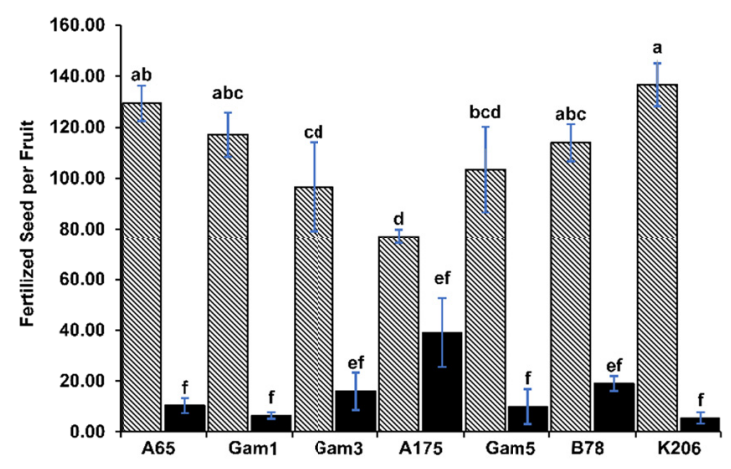

Figure 3. The effect of $\mathrm{GA}_{3}$ on the number of fertilized seeds per fruit in seven tomato genotypes

Note. Shading bars correspond to control and black bars correspond to $\mathrm{GA}_{3}$ application $(0.06 \mathrm{mmol} / \mathrm{L})$. Gamato 1 (Gam1), Gamato 3 (Gam3), Gamato 5 (Gam5), Kaliurang 206 (K206). Bars followed by the same letter are not significantly different at $\mathrm{P} \leq 0.05$. Blue bars are the standard deviation.

Tables 1 and 2 indicated the insignificant differences in seven tomato genotypes and in $\mathrm{GA}_{3}$ treatment between control and treated one on the number of degenerated seeds per fruit, respectively. However, the number of total degenerated seeds per fruit resulted in higher $\mathrm{GA}_{3} 0.06 \mathrm{mmol} / \mathrm{L}$ than the control. Serrani et al. (2007) reported that emasculated ovaries of tomato treated with $\mathrm{GA}_{3}$ induced degenerated ovules. Those results suggested that $\mathrm{GA}_{3}$ inhibited the formation of fertilized seeds and increased the number of degenerated seeds per fruit because $\mathrm{GA}_{3}$ inhibited the pollen from penetrating into the ovary. Ho and Hewitt (1986) reported that the number of fertilized ovules is determined by the success of germinated pollen to reach the micropyle.

\subsection{Fruit Morphology and Quality of Parthenocarpic and Seeded Fruits}

In general, Figure 4A showed that locular cavities of tomato fruit from the responsive genotype treated with gibberellin had expanded internal mesocarp (radial pericarp) and expanded placenta tissue that replaced the ovule position in the locular cavity compared to control as shown in Figure 4C. On the other hand, Figure 4B showed that non-responsive genotype (A175) had a different response whose internal mesocarp was not expanded as well as occurred in responsive genotypes, but almost similar to the untreated as shown in Figure 4D. Finally, that could be used as edible fruit tissue and made more desirable features in fruit. Similar results were reported by Bünger-Kibler and Bangerth (1982) and Serrani et al. (2007) that GA-induced mesocarp cell expanded in tomato.

Table 2. The effect of $\mathrm{GA}_{3}$ Concentration on the number of degenerated seeds per fruit, sugar content (\% Brix), ascorbic acid content (mg/100 g Fresh Weight), and fruit firmness

\begin{tabular}{lllll}
\hline $\mathrm{GA}_{3}$ Concentration mmol/L & $\begin{array}{l}\text { The number of } \\
\text { degenerated seeds per fruit }\end{array}$ & Sugar Content & Ascorbic acid content & Fruit Firmness \\
\hline 0 Control & $4.92 \pm 3.49^{\mathrm{a}}$ & $5.13 \pm 0.54^{\mathrm{b}}$ & $42.35 \pm 5.21^{\mathrm{a}}$ & $43.75 \pm 3.19^{\mathrm{a}}$ \\
0.06 & $10.38 \pm 11.28^{\mathrm{a}}$ & $5.85 \pm 0.73^{\mathrm{a}}$ & $38.25 \pm 5.13^{\mathrm{b}}$ & $43.01 \pm 4.13^{\mathrm{b}}$ \\
\hline
\end{tabular}

Note. Means \pm standard deviation in the column marked with the same lowercase letter are not significantly different at $\mathrm{P} \leq 0.05$.

In order to determine the fruit quality, seeded fruit and seedless fruit were compared to measure the sugar content, ascorbic acid content, and fruit firmness. Table 1 showed that genotypes A65, Gamato 3, and A175 had significantly higher sugar content than Gamato 1, Gamato 5, B78 and Kaliurang 206. This result suggested that genotypes derived from GM1 $\times$ Gondol Hijau had higher sugar content than genotypes derived from GM3 $\times$ Gondol Putih. The application of $\mathrm{GA}_{3} 0.06 \mathrm{mmol} / \mathrm{L}$ increased the significance of sugar content as shown in table 2. The capacity of gibberellin increased the sugar content of seedless fruit has also been reported previously on tomato by Kataoka, Yashiro, Habu, Sunamoto, and Kitajima (2009) and García-Hurtado et al. (2012). The 
expansion of internal mesocarp (radial pericarp) in the locular cavity as shown in Figure 4A may be led to increasing the sugar content due to the high activity of invertase and slightly strengthen the sink activity of developing parthenocarpic fruit (Kataoka et al., 2009; Zhang, Tanabe, Tamura, Itai, \& Yoshida, 2007). Lemaire-Chamley et al. (2005) reported that the expression of sucrose synthase and hexose transporter genes was high during the development of tomato fruit, particularly in exocarp, mesocarp, endocarp, and columella and that expressions are regulated by gibberellin.

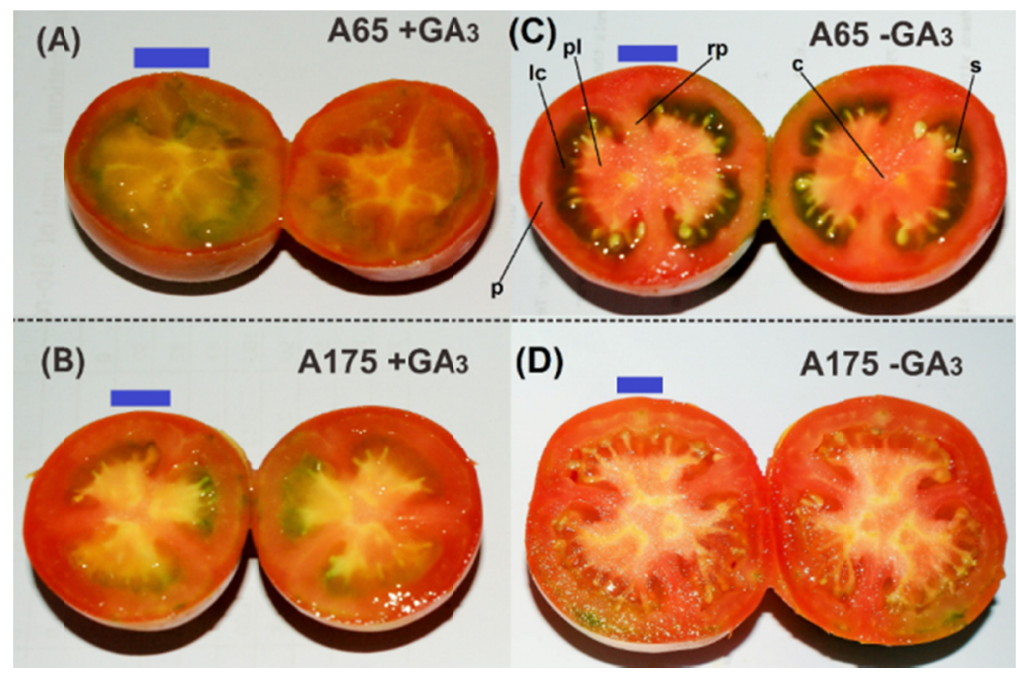

Figure 4. Transverse sections of tomato fruits with the difference of locular cavities between treated and untreated Genotypes

Note. (A) Responsive Genotype i.e. A65 treated with $\mathrm{GA}_{3} 0.06 \mathrm{mmol} / \mathrm{L}$ (seedless) (B) Non-responsive genotype i.e. A175 with $\mathrm{GA}_{3} 0.06 \mathrm{mmol} / \mathrm{L}$ (normal-seeded) (C) A65 with $\mathrm{GA}_{3} 0$ mmol/L. (D) A175 with GA 0 mmol/L. P: pericarp, lc: locular cavity, pl: placenta tissue, rp: radial pericarp, c: Columella (inner wall of pericarp), s: seed. Blue bars $(1 \mathrm{~cm})$.

Table 1 showed that B78 had the highest ascorbic acid content and was significantly different from other genotypes. Gamato 3, Gamato 5, and Kaliurang 206 had the lowest ascorbic acid content. GA 3 treatments significantly reduced the ascorbic acid content as shown in table 2 . The reduction of the ascorbic acid content in GA-induced parthenocarpic fruit was due to the highest transcript of SlGA20ox1 in tomato fruit treated with $\mathrm{GA}_{3} 0.06 \mathrm{mmol} / \mathrm{L}$ which showed a negative correlation with the ascorbic acid content (Unpublished data). A previous study has been reported that SlGA20ox3, one of the three GA20 oxidases involved in the 13-hydroxylation gibberellin biosynthesis pathway, had a negative correlation with the vitamin $\mathrm{C}$ content (Lima-Silva et al., 2012). This result suggested that GA20 oxidase family had a negative effect on the vitamin C content.

B78 had the highest fruit firmness but did not show a significant difference compared to Gamato 1, A175 and Kaliurang 206. A65, Gamato 3 and Gamato 5 showed no significant difference in comparison with Gamato 1, A175, and Kaliurang 206. Table 2 showed that gibberellin application did not affect fruit firmness, and a similar result had also been reported on pepper (Belakbir, Ruiz, \& Romero, 1998) and on the parthenocarpic fruit of tomato compared to the wild type (Andrea Mazzucato, Cellini, Bouzayen, \& Zouine, 2015). This result proved that even parthenocarpic fruit was as firm as seeded fruit.

\section{Summary and Conclusion}

Gibberellin reduced pollen germination and triggered parthenocarpic fruit development. The reduction in the pollen germination and in the number of seeds per fruit affected by $\mathrm{GA}_{3}$ were the key factor for inducing parthenocarpic fruit. Four groups of different degrees of parthenocarpy were distinguished in seven tomato genotypes, high expressivity of parthenocarpy was observed in Kaliurang 206 and A65. However, Kaliurang 206 had a low sugar content, therefore, Gamato 3 can be used together with A65 for inducing parthenocarpy with $\mathrm{GA}_{3}$. Eventhough Gamato 3 was categorized as a medium seeded cultivar, it still produced few seeds. Seedless tomato fruit induced by gibberellin contained more soluble solid and lower ascorbic acid content than seeded 
fruit. Parthenocarpic fruits had valuable features for increasing their potential economic values. Tomato genotypes used in this study are proposed for industrial tomatoes such as the sauce and juice industries. The enhancement of tomato fruit quality with a high sugar content and less acidity is preferable for the consumer. This method has a constraint on its application to indeterminate plants because flowering does not occur simultaneously, so that the spraying of $\mathrm{GA}_{3}$ should be done more thoroughly on each cluster. It is, however, easy to be applied to determinate plants. It is also feasible to adopt this method and apply it to other species, but there is a need to ensure the right and appropriate $\mathrm{GA}_{3}$ concentrations to induce parthenocarpy.

\section{References}

Belakbir, A., Ruiz, J. M., \& Romero, L. (1998). Yield and fruit quality of pepper (Capsicum annuum L.) in response to bioregulators. HortScience, 33(1), 85-87.

Brukhin, V., Hernould, M., Gonzalez, N., Chevalier, C., \& Mouras, A. (2003). Flower development schedule in tomato Lycopersicon esculentum cv Sweet Cherry. Sex. Plant Reprod., 15(6), 311-320. http://dx.doi.org/10.1007/s00497-003-0167-7

Bünger-Kibler, S., \& Bangerth, F. (1982). Relationship between cell number, cell size and fruit size of seeded fruits of tomato (Lycopersicon esculentum Mill.), and those induced parthenocarpically by the application of plant growth regulators. Plant Growth Regulation, 1(3), 143-154. http://dx.doi.org/10.1007/BF00036994

Carmi, N., Salts, Y., Dedicova, B., Shabtai, S., \& Barg, R. (2003). Induction of parthenocarpy in tomato via specific expression of the rolB gene in the ovary. Planta, 217(5), 726-35. http://dx.doi.org/10.1007/s00425-003-1052-1

García-Hurtado, N., Carrera, E., Ruiz-Rivero, O., López-Gresa, M. P., Hedden, P., Gong, F., \& García-Martínez, J. L. (2012). The characterization of transgenic tomato overexpressing gibberellin 20-oxidase reveals induction of parthenocarpic fruit growth, higher yield, and alteration of the gibberellin biosynthetic pathway. Journal of Experimental Botany, 63(16), 5803-13. http://dx.doi.org/10.1093/jxb/ers229

Ho, L. C., \& Hewitt, J. D. (1986). Fruit development. In J. Atherton \& J. Rudich (Eds.), The Tomato Crop (pp. 201-239). Dordrecht: Springer Netherlands. http://dx.doi.org/10.1007/978-94-009-3137-4_5

Jacobs, M. B. (1962). The Chemical Analysis of Foods and Food Products (3rd ed.). New York: D. Van Nostrand Company Inc.

Jung, C. J., Hur, Y. Y., Jung, S. M., Noh, J. H., Do, G. R., Park, S. J., .. Lee, H. J. (2014). Transcriptional changes of gibberellin oxidase genes in grapevines with or without gibberellin application during inflorescence development. Journal of Plant Research, 127(2), 359-371. http://dx.doi.org/10.1007/s10265-013-0623-X

Jung, C. J., Hur, Y. Y., Yu, H.-J., Noh, J.-H., Park, K.-S., \& Lee, H. J. (2014). Gibberellin application at pre-bloom in grapevines down-regulates the expressions of VvIAA9 and VvARF7, negative regulators of fruit set initiation, during parthenocarpic fruit development. PloS One, 9(4), e95634. http://dx.doi.org/10.1371/journal.pone.0095634

Kaganzur, V., Mizrahi, Y., Zamir, D., \& Navot, N. (1991). A Tomato Triploid Hybrid Whose Double Genome Parent Is the Male. Journal of the American Society for Horticultural Science, 116(2), 342-345.

Kataoka, K., Yashiro, Y., Habu, T., Sunamoto, K., \& Kitajima, A. (2009). The addition of gibberellic acid to auxin solutions increases sugar accumulation and sink strength in developing auxin-induced parthenocarpic tomato fruits. Scientia Horticulturae, 123(2), 228-233. http://dx.doi.org/10.1016/j.scienta.2009.09.001

Lemaire-Chamley, M., Petit, J., Garcia, V., Just, D., Baldet, P., Germain, V., ... Rothan, C. (2005). Changes in transcriptional profiles are associated with early fruit tissue specialization in tomato. Plant Physiology, 139(2), 750-769. http://dx.doi.org/10.1104/pp.105.063719

Lima-Silva, V., Rosado, A., Amorim-Silva, V., Muñoz-Mérida, A., Pons, C., Bombarely, A., ... Botella, M. (2012). Genetic and genome-wide transcriptomic analyses identify co-regulation of oxidative response and hormone transcript abundance with vitamin C content in tomato fruit. BMC Genomics, 13(1), 187. http://dx.doi.org/10.1186/1471-2164-13-187

Lukyanenko, A. N. (1991). Parthenocarpy in Tomato. In G. Kallo (Ed.), Monographs on Theoretical and Applied Genetics: Genetics Improvement of Tomato (pp. 167-177). Springer Berlin Heidelberg. http://dx.doi.org/10.1007/978-3-642-84275-7_13

Martí, C., Orzáez, D., Ellul, P., Moreno, V., Carbonell, J., \& Granell, A. (2007). Silencing of DELLA induces 
facultative parthenocarpy in tomato fruits. The Plant Journal, 52(5), 865-876. http://dx.doi.org/10.1111/j.1365-313X.2007.03282.x

Mazzucato, A., Cellini, F., Bouzayen, M., \& Zouine, M. (2015). A TILLING allele of the tomato Aux/IAA9 gene offers new insights into fruit set mechanisms and perspectives for breeding seedless tomatoes. Molecular Breeding, 35, 22. http://dx.doi.org/10.1007/s11032-015-0222-8

Mazzucato, A., Taddei, A. R., \& Soressi, G. P. (1998). The parthenocarpic fruit (pat) mutant of tomato (Lycopersicon esculentum Mill.) sets seedless fruits and has aberrant anther and ovule development. Development (Cambridge, England), 125(1), 107-114.

Okamoto, G., \& Miura, K. (2005). Effect of pre-bloom GA application on pollen tube growth in cv. Delaware grape pistils. Vitis, 44(4), 157-159.

Rotino, G. L., Acciarri, N., Sabatini, E., Mennella, G., Lo Scalzo, R., Maestrelli, A., ... Spena, A. (2005). Open field trial of genetically modified parthenocarpic tomato: Seedlessness and fruit quality. $B M C$ Biotechnology, 5, 32. http://dx.doi.org/10.1186/1472-6750-5-32

Sato, S., Peet, M. M., \& Gardner, R. G. (2004). Altered flower retention and developmental patterns in nine tomato cultivars under elevated temperature. Scientia Horticulturae, 101(1-2), 95-101. http://dx.doi.org/10.1016/j.scienta.2003.10.008

Serrani, J. C., Fos, M., Atarés, A., \& García-Martínez, J. L. (2007). Effect of Gibberellin and Auxin on Parthenocarpic Fruit Growth Induction in the cv Micro-Tom of Tomato. Journal of Plant Growth Regulation, 26(3), 211-221. http://dx.doi.org/10.1007/s00344-007-9014-7

Serrani, J. C., Ruiz-Rivero, O., Fos, M., \& García-Martínez, J. L. (2008). Auxin-induced fruit-set in tomato is mediated in part by gibberellins. The Plant Journal, 56(6), 922-934. http://dx.doi.org/10.1111/j.1365-313X.2008.03654.x

Singh, D., Jermakow, A., \& Swain, S. (2002). Gibberellins are required for seed development and pollen tube $\begin{array}{lllll}\text { growth in } \text { Arabidopsis. The } & \text { 14(12), } & \text { 3133-3147. }\end{array}$ http://dx.doi.org/10.1105/tpc.003046.Arabidopsis

Sugiura, A., \& Inaba, A. (1966). Studies on the mechanism of gibberellin-induced seedlessness of Delaware grapes. I. Journal of the Japanese Society for Horticultural Science, 35(3), 233-241. http://dx.doi.org/10.2503/jjshs.35.233

Tiwari, A., Dassen, H., \& Heuvelink, E. (2007). Selection of sweet pepper (Capsicum annuum L.) genotypes for parthenocarpic fruit growth. Acta Horticulturae, 2007(761), 135-140. http://dx.doi.org/10.17660/ActaHortic.2007.761.16

Varoquaux, F., Blanvillain, R., Delseny, M., \& Gallois, P. (2000). Less is better: New approaches for seedless $\begin{array}{lllll}\text { fruit } & \text { production. }\end{array}$ http://dx.doi.org/10.1016/S0167-7799(00)01448-7

Wang, Q., Lu, L., Wu, X., Li, Y., \& Lin, J. (2003). Boron influences pollen germination and pollen tube growth in Picea meyeri. Tree Physiology, 23(5), 345-351. http://dx.doi.org/10.1093/treephys/23.5.345

Zhang, C., Tanabe, K., Tamura, F., Itai, A., \& Yoshida, M. (2007). Roles of gibberellins in increasing sink demand in Japanese pear fruit during rapid fruit growth. Plant Growth Regulation, 52(2), 161-172. http://dx.doi.org/10.1007/s10725-007-9187-x

\section{Copyrights}

Copyright for this article is retained by the author(s), with first publication rights granted to the journal.

This is an open-access article distributed under the terms and conditions of the Creative Commons Attribution license (http://creativecommons.org/licenses/by/3.0/). 